\title{
Cultivo de embriões bovinos produzidos in vitro: efeito do número de embriões e da proporção de meio
}

Daniela dos Santos BRUM ${ }^{1,3}$

Fábio Gallas LEIVAS ${ }^{1,3}$

Mari Lourdes BERNARDI ${ }^{2}$

Fabrício Desconzi

MOZZAQUATRO ${ }^{1,3}$

Carlos Antonio Mondino

SILVA ${ }^{3}$

Mara Iolanda Batistella

RUBIN $^{3}$

\section{Correspondência para:}

DANIELA DOS SANTOS BRUM

Embryolab - Laboratório de Embriologia

Animal

Departamento de Clínica de Grandes

Animais

Hospital Veterinário

Centro de Ciências Rurais

Universidade Federal de Santa Maria.

97.105-900 Santa Maria, RS.

embryolab@ufsm.br

Recebido para publicação: 12/05/2004 Aprovado para publicação: 21/09/2005

\author{
1 - Programa de Pós-Graduação em Medicina Veterinária da Universidade \\ Federal de Santa Maria, Santa Maria - RS \\ 2 - Departamento de Zootecnia da Faculdade de Agronomia da \\ Universidade Federal do Rio Grande do Sul,Porto Alegre - RS \\ 3 - Laboratório de Embriologia Animal do Hospital Veterinário da \\ Universidade Federal de Santa Maria, Santa Maria - RS
}

\section{Resumo}

Na última década, os produtores de leite e carne bovina incrementaram consideravelmente o uso da aspiração folicular (OPU) associada à produção in vitro de embriões (IVP). Oócitos recuperados pela OPU têm qualidade diversificada e seu número reduzido requer condições diferenciadas de cultivo para a IVP. Para determinar o efeito do número de embriões e volume de meio sobre a IVP, 1428 embriões bovinos foram cultivados em grupos de 5, 10 e 20, em 1:1, 1:5 e 1:10mL de meio. Grupos de 20 oócitos foram maturados in vitro em $200 \mathrm{~mL}$ de TCM-199+ rFSHh+10\% de soro de vaca em estro (SVE), por $24 \mathrm{~h}$. A fecundação in vitro foi em grupos de 20 oócitos $/ 200 \mathrm{~mL}$ de meio FertTalp, por $18 \mathrm{~h}$ com $1 \times 10^{6}$ espermatozóides $/ \mathrm{mL}$. O cultivo foi em SOFaaci $+5 \%$ SVE por 8 dias. Considerando-se o dia da fecundação como D0, conduziu-se as avaliações no D2 (clivagem), D7 (blastocistos) e no D9 (eclosão). A taxa de clivagem foi superior quando o cultivo foi com 20 embriões e não foi afetada quando a proporção de meio variou (1:1; 1:5 e 1:10). Com as proporções de meio de cultivo 1:5 ou 1:10, a taxa de embriões em D7 foi superior $(\mathrm{P}<0.05)$ à $1: 1$. O número de embriões cultivados influenciou a produção de blastocistos em D7 ( $<<0,05)$ com 20 embriões/gota. Estes resultados também se refletem nos percentuais de blastocistos eclodidos em $\mathrm{D}$ 9, sendo que 1:5 e 1:10 foram superiores $(\mathrm{P}<0,05)$ à 1:1. Da mesma forma, a taxa de eclosão foi superior $(\mathrm{P}<0,05)$ com o cultivo de 10 ou 20 embriões/gota quando comparado ao grupo de 5 embriões/gota. A redução do número de embriões e da proporção de volume de meio no cultivo, afeta os índices de desenvolvimento na produção in vitro de embriões bovinos.

\section{Introdução}

O cultivo embrionário, realizado logo após o período de fecundação in vitro (FIV), é fundamental para o sucesso na produção in vitro (PIV) de embriões bovinos. O sistema empregado nessa etapa deve proporcionar condições adequadas para as primeiras clivagens, ativação do genoma embrionário e conseqüente desenvolvimento até o estágio de blastocisto, nos programas comerciais ou de pesquisa, visando a transferência para as receptoras. Atualmente, diversos sistemas vêm sendo empregados com sucesso, todos eles tentando mimetizar ao máximo as condições uterinas. No entanto, a tuba uterina e o útero apresentam várias alterações no decorrer do desenvolvimento embrionário, o que os torna um sistema muito complexo e de difícil reprodução in vitro. Além do uso de condições atmosféricas adequadas e meios de cultivo que supram as necessidades 
1 Sigma Chemical CO. - P.O. Box 4508 MO., USA.

2 Nevoni Equipamento Odonto Médico Hospitalar Brasil Ltda. Rua Dom João V, 266 280 Lapa 05.075-060 São Paulo, SP. Brasil. 3 Carl Zeiss - 73446, Oberkochen, Alemanha.

4 Gibco BRL - Grand Island NY. $14072-$ 0068, USA. Ref. 31100-027

5 Serono Pharma S.p.A- 70123, Bari, Itália. 6 W.C. Heraeus GmbH. Postfach 1553 D6450 Hanau 1, Alemanha. metabólicas dos embriões nas suas diferentes etapas de desenvolvimento, o número de embriões utilizados por gota, assim como o volume dessas gotas, são fatores que contribuem na obtenção de bons índices de desenvolvimento embrionário. Os inconstantes resultados obtidos na PIV estão relacionados aos diferentes sistemas utilizados e, especialmente, à densidade de embriões empregada durante o cultivo.

Nos trabalhos realizados até o momento foi demonstrado que embriões cultivados em grupos apresentam maiores índices de desenvolvimento ${ }^{1,2,3}$, embora seja possível obter bons resultados com o cultivo individual $^{4,5,6,7}$. No entanto, há divergência quanto ao volume ideal de meio a ser empregado durante o cultivo in vitro (CIV), existindo atualmente grande variabilidade nos protocolos e entre laboratórios. Os volumes de meios utilizados estão adequados a protocolos de pesquisa, nos quais, de modo geral, os embriões são cultivados em grupos com o número de embriões pré-determinado e, geralmente, em grandes grupos (20 a 40 embriões). Dessa forma, não é analisado se a redução na densidade de embriões por gota poderia causar prejuízos ou mesmo benefícios ao desenvolvimento embrionário.

Com a crescente demanda comercial da PIV de embriões bovinos na última década, surge a necessidade de pesquisas que visem criar protocolos mais direcionados à produção de embriões a partir de oócitos obtidos da OPU (Ovum Pick Up). Nesse sistema de punção in vivo, o número de oócitos obtidos por doadora é relativamente baixo, quando comparado ao utilizado em condições experimentais. Esse estudo teve como objetivo avaliar o efeito do número de embriões por gota de meio e de diferentes proporções de meio por embrião, durante o cultivo de embriões bovinos produzidos in vitro.

\section{Materiais e Métodos}

Os embriões foram produzidos a partir de oócitos de ovários de matadouro transportados até o laboratório à temperatura de 22 e $25^{\circ} \mathrm{C}^{8}$, em solução fisiológica a $0,9 \%$ de $\mathrm{NaCl}^{1}$ acrescida de $100 \mathrm{mg}$ de estreptomicina ${ }^{1}$ e 50.000 UI de penicilina GPotássica ${ }^{1}$ para um litro de solução, em tempo não superior a quatro horas após o término do abate. Os folículos com diâmetro entre 2 e $8 \mathrm{~mm}$ foram puncionados com o auxílio de uma bomba de vácuo ${ }^{2} \mathrm{e}$ os Complexos Cumulus-oócitos (CCO) aspirados foram mantidos em líquido folicular durante a identificação, sob estereomicroscópio ${ }^{3}$. A seleção dos CCO foi conduzida imediatamente, de acordo com o aspecto morfológico, conforme o critério de avaliação descrito por De Loos et al. ${ }^{9}$, utilizando-se CCO de qualidade I e II.

A maturação foi realizada em gotas de $200 \mathrm{~mL}$ de TCM-1994 (sais de Earle) modificado, adicionado de $5,95 \mathrm{mg} / \mathrm{mL}$ de HEPES $^{1}, 0,025 \mathrm{mg} / \mathrm{mL}$ de piruvato de sódio $^{1}, 0,01 \mathrm{UI}$ de $\mathrm{rFSHh} / \mathrm{mL}^{5}$ e $10 \%$ de soro de vaca em estro (SVE), sob óleo mineral por um período de 22 a 24 horas, em estufa de cultivo a $38,5^{\circ} \mathrm{C}$, com $5 \%$ de $\mathrm{CO}_{2}$ em ar e umidade saturada.

Para a fecundação utilizou-se sêmen congelado em palhetas de $0,5 \mathrm{~mL}$ de um touro Bos taurus, cujo descongelamento foi efetuado em banho-maria a $39^{\circ} \mathrm{C}$ por 20 segundos. O sêmen foi submetido ao processo de migração ascendente em meio TALP-SPERM ${ }^{10}$, acrescido de $6 \mathrm{mg} / \mathrm{mL}$ $\mathrm{BSA}^{1}$ e $0,11 \mathrm{mg} / \mathrm{mL}$ de piruvato de sódio. A dose inseminante foi de $1 \times 10^{6}$ espermatozóides $/ \mathrm{mL}$. A incubação dos oócitos/espermatozóides foi conduzida em meio TALP-FERT ${ }^{10} \mathrm{com} 6 \mathrm{mg} / \mathrm{mL}$ de albumina sérica bovina ${ }^{1}(\mathrm{BSA}), 0,022 \mathrm{mg} / \mathrm{mL}$ de piruvato de sódio, heparina $(30 \mathrm{mg} / \mathrm{mL})^{1}$ e PHE $^{1}$ (penicilamina, hipotaurina e epinefrina) em estufa de cultivo celular ${ }^{6}$ a $38,5^{\circ} \mathrm{C}$, com $5 \%$ de $\mathrm{CO}_{2}$ em ar e umidade saturada, pelo período de 18 a 22 horas.

Os supostos zigotos foram desnudados por sucessivas passagens no interior de uma pipeta e distribuídos aleatoriamente nos diferentes tratamentos, com distintos números 
de embriões e volumes de meio cultivo SOFaaci ${ }^{11}$ com $5 \%$ de soro de vaca em estro (SVE). Nestas condições, os embriões permaneceram por 8 dias, sob óleo minera $1^{12}$, em estufa à temperatura de $38,5^{\circ} \mathrm{C}$, com $5 \%$ de $\mathrm{CO}_{2}$ em ar e umidade saturada.

\section{Resultados}

O efeito do dia da realização da PIV foi significativo e mantido no modelo de análise estatística. Não houve interação entre o número de oócitos e a proporção de volume $(\mathrm{P}>0,05)$. A taxa de clivagem foi influenciada $(\mathrm{P}<0,05)$ pelo número de embriões, mas não pela proporção de meio $(\mathrm{P}>0,05)$. Taxa de clivagem superior foi observada com 20 embriões em comparação a 10 e 5 (Tabela 1).

O desenvolvimento em D7 foi influenciado tanto pelo número de embriões como pela proporção de meio $(\mathrm{P}<0,05)$. Taxas de desenvolvimento superiores foram observadas em D7, com 10 e 20 embriões e com as proporções de meio de 1:5 e 1:10mL (Tabelas 1 e 2). As taxas de eclosão em relação ao número de embriões em D7 não foram afetadas $(\mathrm{P}>0,05)$ pelo número de embriões, nem pela proporção de meio (Tabelas 1 e 2). Considerando a taxa de eclosão sobre o total de clivados, mantevese esta superioridade com 10 e 20 embriões / gota, comparados com grupos de 5 embriões/gota de cultivo e 5 e $10 \mu \mathrm{L}$ de meio, em comparação a $1 \mu \mathrm{L}$.

\section{Discussão}

O efeito benéfico do cultivo de embriões em grupo já foi comprovado em várias espécies ${ }^{12,13,14,15,16,17,18}$. Esse benefício ocorre devido à produção de fatores de crescimento pelos próprios embriões que, pela ação autócrina e parácrina que auxiliam no desenvolvimento embrionário ${ }^{19,20,21}$. Quando a maioria dos sistemas de cultivo empregavam o co-cultivo dos embriões com diferentes tipos de células somáticas, este efeito ficava mascarado, devido à cooperação existente entre essas células. No entanto, na maioria dos sistemas atuais de produção in vitro de embriões, tenta-se reduzir ao máximo a utilização do soro como fonte protéica, além de evitar o co-cultivo com células somáticas. No presente estudo foi observada redução gradativa no desenvolvimento embrionário em D9, quando se reduziu o número de embriões por gota (de 20 para 10 e 5). Resultados semelhantes foram observados por outros autores quando reduziram o número de embriões cultivados por gota ${ }^{1,2,3,5} . \mathrm{Na}$ tentativa de obter melhores índices de produção com grupos menores, alguns autores sugerem a utilização de embriões de outras espécies como camundongos, associados ao cultivo in vitro de embriões bovinos ou o cultivo de embriões em meios onde já foram cultivados embriões ou células do oviduto ${ }^{22,23}$, buscando o aproveitamento de fatores contidos no meio de cultivo. Ainda com o propósito de aumentar a densidade de embriões, Salahuddin et al. ${ }^{17}$ tentaram sem sucesso o cultivo de embriões de camundongo com estruturas degeneradas ou não fecundadas.

Os meios utilizados atualmente para o cultivo de embriões estão cada vez mais complexos, enriquecidos com diferentes fatores de crescimentos, vitaminas e aminoácidos. Embora se saiba que os aminoácidos são benéficos ao desenvol-vimento embrionário, eles são metaboliza-dos espontaneamente pelos embriões em temperaturas entre 37 e $39^{\circ} \mathrm{C}$, resultando em acréscimo significativo de amônia no meio de cultivo ${ }^{12}$. A amônia, em altas concen-trações, possui efeito tóxico para células somáticas e embriões. Baseado nesses fatos, tem sido sugerida a redução do número de embriões por gota, aumento no volume da gota ou a troca de meio durante o cultivo, na tentativa de reduzir a influência de altas concentrações de fatores tóxicos ${ }^{24}$. Embora seja sugerida a utilização de um volume reduzido de meio durante o cultivo, buscando manter maior concentração de fatores de crescimento no local ${ }^{20}$, no presente trabalho, essa redução resultou em 
menor produção de blastocistos. Em trabalho realizado por pesquisadores brasileiros, foi constatado que embriões bovinos podem ser cultivados em proporções de meio que variam de 1:1 até 1:20mL, desde que os grupos sejam de 25 embriões. No entanto, nesse mesmo trabalho ficou evidenciado o alto índice de embriões degenerados, assim como a ausência de eclosão, quando foi utilizado o volume de $1 \mathrm{~mL}$ meio para cada embrião ${ }^{25}$. Palasz e Thindathil ${ }^{26}$ obtiveram menor produção de blastocistos quando cultivaram embriões em grupos de 5 ou 10 , em comparação a grupos de 20. No entanto, esses autores obtiveram índices superiores em proporções de 2:1 (embrião:mL de meio), quando comparado com 1:2,5mL; contrastando com os resultados obtidos no presente trabalho, no qual a proporção de $1: 1 \mathrm{~mL}$ foi prejudicial ao desenvolvimento embrionário. Diversos fatores podem estar associados a essa redução no desenvolvimento embrionário, como o acúmulo de metabólitos, por exemplo de amônia, ou de altas concentrações de radicais livres no meio de cultivo $^{24,27}$. Já foi comprovado o efeito negativo ocasionado pelo estresse oxidativo, em diferentes células de mamíferos, inclusive embriões, proporci-onado pela alta tensão de oxigênio ${ }^{28}$. A atmosfera gasosa utilizada no presente trabalho foi de $5 \%$ de $\mathrm{CO}_{2}$, o que pode ter contribuído para a redução do desenvolvimento embrionário, quando utilizados volumes menores de meio. Além disso, também não foi utilizado o co-cultivo com células somáticas que, além de secretarem substâncias embriotróficas e remover fatores inibitórios, são capazes de reduzir a tensão de $\mathrm{O}_{2}$. Outros autores obtiveram bons resultados com o cultivo em pequenos volumes de meio, até mesmo utilizando o cultivo individual, mas na maioria dos casos foi utilizada atmosfera com oxigênio controlado ${ }^{6,7}$. No presente estudo a quantidade de óleo mineral que cobria as gotas de cultivo não foi adaptada conforme o volume da gota. Isto pode ter ocasionado uma menor relação óleo:meio de cultivo em gotas com volumes maiores, resultando em maiores trocas do meio de cultivo com o meio externo ${ }^{23}$. No entanto, as gotas menores, embora menos suscetíveis às trocas gasosas com a atmosfera, sofreram maior contato com o óleo que, embora seja um produto testado para embriões, muitas vezes contém substâncias tóxicas que inibem o desenvolvimento embrionário, o que poderia ter contribuído para os menores índices obtidos em proporções menores de meio.

A não ocorrência de efeito significativo da interação do número de embriões com o volume de meio mostra que quando trabalha-se com número pequeno de embriões, não há vantagens em ajustar o volume de meio. Por outro lado, o efeito prejudicial da menor proporção de meio manifesta-se tanto em grupos com menor (5) como em maior número (20). É importante ressaltar que esses resultados estão diretamente associados ao sistema de produção empregado no cultivo dos embriões. As proporções de embriões e de

Tabela 1 - Efeito do número de embriões por gota de cultivo sobre a produção in vitro em bovinos

\begin{tabular}{|c|c|c|c|c|c|}
\hline \multirow[b]{2}{*}{$\begin{array}{l}\text { Número } \\
\text { de } \\
\text { embriões } \\
\text { PIV }\end{array}$} & \multirow{2}{*}{$\begin{array}{c}\text { Complexos } \\
\text { Cumulus- } \\
\text { oócitos } \\
\text { maturados } \\
n\end{array}$} & \multicolumn{4}{|c|}{ Desenvolvimento embrionário } \\
\hline & & $\begin{array}{c}\text { Clivados em } \\
\text { D2 } \\
\mathrm{n}(\%)\end{array}$ & $\begin{array}{c}\text { Blastocistos em } \\
\text { D7 } \\
\mathrm{n}(\%)\end{array}$ & $\begin{array}{c}\text { Eclosão/D2 * } \\
\text { n (\%) }\end{array}$ & $\begin{array}{c}\text { Eclosão/D7** } \\
\text { n (\%) }\end{array}$ \\
\hline 5 & 475 & $364(76,6)^{a}$ & $78(16,4)^{\mathrm{a}}$ & $27(7,4)^{\mathrm{a}}$ & $27(34,6)^{a}$ \\
\hline 10 & 480 & $372(77,5)^{\mathrm{a}}$ & $98(20,4)^{b}$ & $44(11,8)^{b}$ & $44(44,9)^{\mathrm{a}}$ \\
\hline 20 & 473 & $418(88,4)^{b}$ & $122(25,8)^{c}$ & $58(13,9)^{b}$ & $58(47,5)^{\mathrm{a}}$ \\
\hline
\end{tabular}

Letras diferentes, na mesma coluna, indicam diferença significativa $(\mathrm{P}<0,05)$.

*Calculado sobre total de clivados ** Calculado sobre blastocistos em D7. Local: Embryolab- UFSM, RS Data: Abril de 2004 
Tabela 2 - Efeito da proporção do volume de meio no cultivo sobre a produção in vitro de embriões bovinos

\begin{tabular}{|c|c|c|c|c|c|}
\hline \multirow{2}{*}{$\begin{array}{l}\text { Proporção de } \\
\text { embriões/ } \\
\text { meio de } \\
\text { cultivo }\end{array}$} & \multirow{2}{*}{$\begin{array}{l}\text { Complexos } \\
\text { Cumulus- } \\
\text { oócitos } \\
\text { maturados } \\
\text { n }\end{array}$} & \multicolumn{4}{|c|}{ Desenvolvimento embrionário } \\
\hline & & $\begin{array}{c}\text { Clivados em } \\
\text { D2 } \\
n(\%)\end{array}$ & $\begin{array}{c}\text { Blastocistos em } \\
\text { D7 } \\
\mathrm{n}(\%)\end{array}$ & $\begin{array}{c}\text { Eclosão/clivado } \\
\mathrm{s}^{*} \\
\mathrm{n}(\%)\end{array}$ & $\begin{array}{c}\text { Eclosão/D7 } \\
* * \\
\mathrm{n}(\%)\end{array}$ \\
\hline $1: 1 \mu \mathrm{L}$ & 474 & $374(78,9)^{\mathrm{a}}$ & $78(16,5)^{\mathrm{a}}$ & $28(7,5)^{\mathrm{a}}$ & $74(35,9)^{\mathrm{a}}$ \\
\hline $1: 5 \mu \mathrm{L}$ & 476 & $388(81,5)^{\mathrm{a}}$ & $109(22,9)^{b}$ & $49(12,6)^{b}$ & $110(44,9)^{b}$ \\
\hline $1: 10 \mu \mathrm{L}$ & 478 & $392(82,0)^{\mathrm{a}}$ & $111(23,2)^{b}$ & $52(13,3)^{b}$ & $110(46,8)^{b}$ \\
\hline
\end{tabular}

Letras diferentes, na mesma coluna, indicam diferença significativa $(P<0,05)$

*Calculado sobre total de clivados ** Calculado sobre blastocistos em D7. Local: Embryolab - UFSM, RS Data: Abril de 2004

volume utilizadas no presente estudo deveriam ser avaliadas em outros sistemas, como aquele com tensão reduzida de $\mathrm{O}_{2}$, troca de meio ou acréscimo ao longo do cultivo, entre outros, a fim de obter maior conhecimento nesse sentido.

\section{Conclusões}

A produção in vitro de embriões bovinos é superior com o cultivo em grupos de 10 ou 20, ao invés de 5 embriões. As proporções de 1 embrião para $5 \mathrm{~mL}$ e $10 \mathrm{~mL}$ de meio de cultivo incrementam as taxas de produção de blastocistos, sendo recomen-dadas para os programas comerciais e de pesquisa.

\section{Agradecimentos}

Ao Prof. Dr. Carlos Augusto Mallmann do LAMIC (UFSM) pelo apoio à pesquisa, à PECPLAN-ABS Rosário do Sul, RS, pela assistência técnica/auxilio no preparo do sêmen, aos Frigoríficos Silva (Santa Maria) e JG (Caçapava do Sul) que gentilmente cederam os ovários bovinos para este estudo.

\section{Culture of in vitro produced bovine embryos: effect of number of embryos and medium ratio}

\section{Abstract}

In the last decade the dairy and beef bovine farms had an increment in their breeding programs that include the use o ovum pick-up and in vitro production (OPU/IVP). Oocytes retrieved by OPU vary in quality and its reduced number requires appropriated culture conditions for IVP. To evaluate the effect of the number of embryos and volume of the media in the in vitro culture of bovine embryos, 1428 zygotes were cultured in groups of 5,10 or 20 in 1,5 or $10 \mathrm{~mL}$ of medium. Groups of 20 oocytes matured in vitro in $200 \mathrm{~mL}$ of $\mathrm{TCM}+\mathrm{rFSHh}+10 \%$ estrus cow serum (ECS). The fertilization was performed in groups of 20 oocytes $/ 200 \mathrm{~mL}$ of Fert-Talp medium, for $18 \mathrm{~h}$ with $1 \times 10^{6}$ spermatozoa $/ \mathrm{mL}$. The culture was done in SOFaaci $+5 \% \mathrm{ECS}$ for 8 days. Considering D 0 as the fertilization day, the IVP was evaluated on day 2 (cleavage), day 7 (blastocyst) and in day 9 (hatching rates). The cleavage rates were higher when embryos were cultured in groups of twenty. However, it was not affected by the medium ratio of $1: 1,1: 5$ and $1: 10$. The use of $1: 5$ and $1: 10 \mathrm{~mL}$ of culture medium ratio showed higher embryo production rates in $\mathrm{D} 7$ $(\mathrm{P}<0.05)$ than $1: 1 \mathrm{~mL}$ proportion. The culture of 20 embryos per drop affected the blastocyst production on day 7. Likewise the hatching
Key-words: bovine embryos. Culture.

IVP.

OPU. 
rates in D9 were higher with 1:5 and 1:10 than 1:1. Similarly, the hatching rates were higher in cultured of 10 or 20 embryos/drop when compared to groups of 5 embryos/drop. The reduction of embryos and the proportion of the medium volume in culture affects the development indexes on bovine embryos in vitro production.

\section{Referências}

1 DONNAY, I. et al. Effects of co-culture and embryo number on the in vitro development of bovine embryos. Theriogenology, v. 47, n. 8, p.1549-1561, 1997.

2 O'DOHERTY, E. M.; WADE, M. G.; HILL, J. L. Effects of culturing bovine oocytes either singly or in groups on development to blastocysts. Theriogenology, v. 48 , n. 1, p.161-169, 1997.

3 KHURAMA, N. K.; NIEMEN, H. Effects of oocyte quality, oxygen tension, embryo density, Cumulus cells and energy substrates on cleavage and morula/blastocyst formation of bovine embryos. Theriogenology, v. 54, n. 5, p. 741-756, 2000.

4 BLONDIN, P. et al. In vitro production of bovine embryos: developmental competence is acquired before maturation. Theriogenology, v. 47, n. 5, p. 1061-1075, 1997.

5 FUKUI, Y. et al. Fertilizability and developmental capacity of individually cultured bovine oocytes. Theriogenology, v. 53, n. 8, p. 1553-1565, 2000.

6 HOLM, P.; VAJTA, G.; BOOTH, P. J. In vitro production of bovine embryos cultured in groups in wells or singly in the wow-system in a defined or undefined SOFaa medium. Theriogenology, v. 53, n. 1 , p. 296, 2000.

7 VAJTA, G. et al. A new method for individual embryo culture: the well of the well (WOW) system. Theriogenology, v. 53, n. 1, p. 304, 2000.

8 YANG,N. S.; LU, K. H.; GORDON, I. In vitro fertilization (IVF) and culture (IVC) of bovine oocytes from ovaries storage. Theriogenology, v. 33, n. 1, p. 352, 1990.

9 De LOOS F. et al. Morphology of immature bovine oocyte. Gamete Research, v. 24, n. 8, p. 197-204, 1989.

10 PARRISHI, J. J.; SUSKO-PARRISH, J.; LEIBFRIEDRUTLEDGE, M.; CRITSER, E. S.; EYESTONE, W. H.; FIRST, N. L. Bovine in vitro fertilization with frozenthawed semen. Theriogenology, v. 25, n. 4, p. 591600, 1986.

11 HOLM P. et al. High bovine blastocyst development in a static in vitro production system using SOFaa medium supplemented with sodium citrate and myo-inositol with or without serum-proteins. Theriogenology, v. 52, n. 4, p. 683-700, 1999.

12 GARDNER, D. K. et al. Enhanced rates of cleavage and development for sheep zygotes cultured to the blastocyst stage in vitro in the absence of serum and somatic cells: amino acids, vitamins, and culturing embryos in groups stimulate development. Biology of Reproduction, v. 50, n. 2, p. 390-400, 1994

13 WILEY, L. M.; YAMANI, S.; VAN MUYDEN, D. Effect of potassium concentration, type of protein supplement, and embryo density on mouse preimplantation development in vitro. Fertility and Sterility, v. 45, n. 1, p. 111-119, 1986.

14 PARIA, B. C.; DEY, S. K. Preimplantation embryo development in vitro: cooperative interaction among embryos and role of growth factors. Proccedings of National Academy Sciences, Washington, USA. v. 87, p. 4756-4760, 1990.

15 LANE, M.; GARDNER, D. K. Effect of incubation volume and embryo density on the development in vitro and in vivo. Human Reproduction, v. 7, n. 4, p. 558-562, 1992.

16 KATO, Y.; TSUNODA, Y. Effects of the culture density of mouse zygotes on the development in vitro and in vivo. Theriogenology, v. 41, n. 6, p. 1315-1322, 1994.

17 SALAHUDDIN, N. S. et al. Effects of embryo density and co culture of unfertilized oocytes on embryonicdevelopment of in-vitro fertilized mouse embryos. Human Reproduction, v. 10, n. 9, p. 2382-2385, 1995.

18 WARD, F. A.; ENRIGHT, B. P.; BOLAND, M. P. Effect of group size and oocyte to medium volume postfertilization on the development of bovine embryos in vitro. Theriogenology, v. 53, n. 1, p. 306, 2000.

19 KEEFER, C. L. et al. In vitro culture of bovine IVMIVF embryos: cooperative interaction among embryos and the role of growth factors. Theriogenology, v. 42, n. 7, p. 323-1331, 1994

$20 \mathrm{KITO}$, S.; IRITANI, A.; BAVISTER, B. D. Effects of volume, culture media and type of culture dish on in vitro development of hamster 1-cell embryos. Theriogenology, v. 47, n. 2, p. 541-548, 1997.

21 THIBOUDEAUX, J. K.; MYERS, M. W.; HANSEL, $W$. The beneficial effects of incubating bovine embryos in groups are dur to platelet-derived growth factor. Theriogenology, v. 43, n. 1, p. 336, 1995.

22 LI, L. Y.; DENNISTON, R. S.; GODKE, R. A. Enhanced development of IVF-derived bovine embryos by culturing with mouse embryos. Theriogenology, v.39, n.1, p.259, 1993.

23 FERRY, L.; MERMILLOD, P.; MASSIP, A. Bovine embryos cultured in serum-poor oviduct-conditioned medium need cooperation to reach the blastocyst stage. 
Theriogenology, v. 42, n. 3, p. 445-453, 1994.

24 IKEDA, K.; TAKAHASHI, Y.; KATAGIRI, S. Effect of medium change on the development of in vitro matured and fertilized bovine oocytes cultured in medium containing amino acids. Journal of Veterinary Medicine Science, v. 62, n. 1, p. 121-123, 2000.

25 SCHWEITZER, C. M. et al. Efeito de diferentes volumes de meio de cultivo no desenvolvimento embrionário in vitro em bovinos. Arquivos da Faculdade de Veterinária da UFRGS, v. 28, n. 1, p. 242, supl. 1, 1996.

26 PALASZ, A. T.; THINDATHIL, J. The effect of volume of culture medium and embryo density on in vitro development of bovine embryos. Theriogenology, $v$. 49 , n. 1 , p. 212,1998

27 TAKAHASHI, Y.; KANAGAWA, H. Effect of oxygen concentration in the gas atmosphere during in vitro insemination of bovine oocytes on the subsequent embryonic development in vitro. Journal of Veterinary Medical Science, v. 60, n. 3, p. 365-367, 1998.

28 BAVISTER, B. D. Culture of preimplantation embryo: facts and artifacts. Human Reproduction Update, v. 1 , n. 1, p. 91-148, 1995.

29 AHERN, T. J.; GARDNER, D. K. Culturing bovine embryos in groups stimulates blastocyst development and cell allocation to the inner cell mass. Theriogenology, v. 49, n. 1, p. 194, 1998.

30 SAS Institute (Cary NC) SAS user's guide: Statistical Analysis System, Release 6.12, 1998.

31 YUAN Y. Q. et al. Single embryo culture affects hatching rate in bovine in vitro produced embryos. Theriogenology, v. 53, n. 1, p. 307, 2000. 